
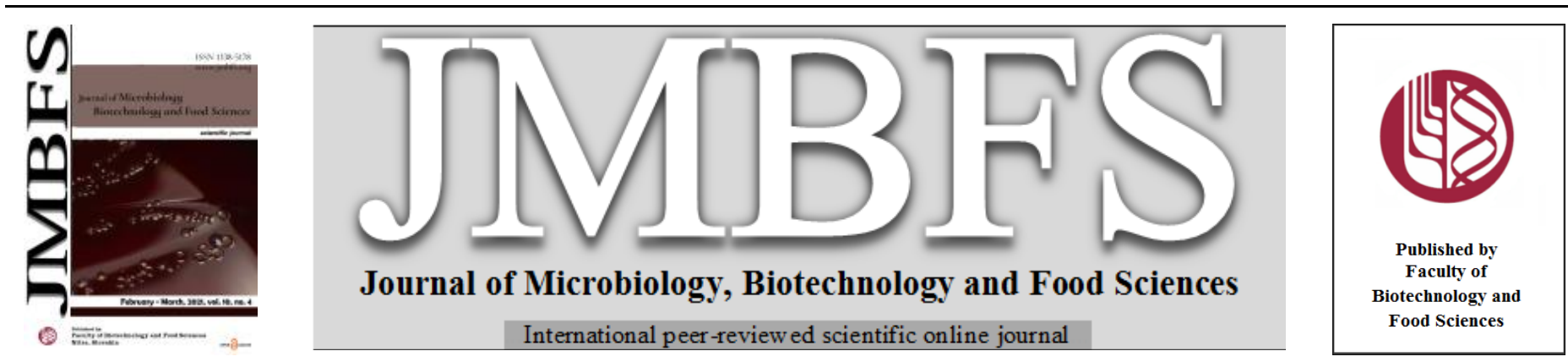

\title{
HARNESSING THE NUTRITIONAL QUALITY OF PAWPAW AND PINEAPPLE FRUITS FOR PILOT SCALE PRODUCTION OF WINE
}

\author{
Olufemi Emmanuel Bankefa ${ }^{* 1}$, Seye Julius Oladeji ${ }^{2}$, Ruth A. Gabriel-Ajobiewe ${ }^{1}$, Hafiz Awofe Akinyele ${ }^{1}$, Solomon Mayowa Samuel ${ }^{1}$
}

Address(es): Olufemi Emmanuel Bankefa,

${ }^{1}$ Federal University Oye-Ekiti, Faculty of Science, Department of Microbiology, Oye-Are 3, 371104, Oye-Ekiti, Ekiti State, Nigeria, phone number: +2348038736908 : ${ }^{2}$ South China University of Technology, School of Food Science and Engineering, Wushan Road, Tianhe District, 381, 510641, Guangzhou, Guangdong, China.

*Corresponding author: olufemi.bankefa@fuoye.edu.ng, femibankefa@gmail.com

doi: 10.15414/jmbfs.2021.10.4.663-668

\section{ARTICLE INFO}

Received 12.3. 2020

Revised 29. 10. 2020

Accepted 5. 11.2020

Published 1. 2. 2021

Regular article OPEN $\partial_{\text {ACCESS }}$

\begin{abstract}
Fermenting blended fruits has been observed to have positive cumulative health benefits. Pawpaw and Pineapple have well-known nutritive and health benefits. This study evaluated the role of fermentation on the nutritional and anti-nutritional compositions of pawpaw-pineapple juice blends using single and mixed starter cultures. Fermentation of pawpaw-pineapple juice blends in varying ratios: 1:1, 1:3 and 3:1 tagged Samples A, B, and C respectively was performed for five days after which the nutritional and antinutritional compositions were analyzed using standard methods. The findings revealed an increase in the concentration of all the proximate parameters except carbohydrate. The results also showed that sample A was better in nutritive quality than sample B and C by $8.55 \%$ and $3.92 \%$ respectively. The mono-cultural fermentation of sample A by Saccharomyces cerevisiae yielded the highest nutritional value (30.12\%) as compared to mixed (25.35\%) and single culture fermentation of Lactobacillus delbreukii (23.40\%) and Leuconostoc mesenteroides (21.13\%). The mineral composition of sample A $(37.60 \%)$ with respect to organism was also observed to be significantly higher than sample B $(28.82 \%)$ and C (33.58\%). Overall, the single culture of S. cerevisiae gave the highest mineral output in all the blended ratios. The levels of the anti-nutrients were better reduced by a single culture of $S$. cerevisiae. Furthermore, the monocultural fermentation of sample A by S. cerevisiae produced the highest alcoholic content. Mono-cultural fermentation of pawpawpineapple juice in ratio $1: 1$ by $S$. cerevisiae is most efficient in obtaining the highest nutritional value and alcoholic content in pawpawpineapple wine.
\end{abstract}

Keywords: Pawpaw-Pineapple Wine, Food Insecurity, Malnutrition, Fermentation, Nutrient, Pilot Scale

\section{INTRODUCTION}

Food insecurity and malnutrition are threatening issues in both the developed and developing world, despite all the efforts to combat them (Chikwendu et al., 2014). Global nutrition survey reveals that most dietary deficiencies are of protein with high biological value (Latham, 1997). Consequently, legumes and cereal grains have received great attention lately and probably little attention on fruits, because animal foods which are rich in protein are beyond the rich of majority of the population due to high costs (Chikwendu et al., 2014). Fruits are one of the most important foods of mankind, indispensable for the maintenance of health and improve the quality of our diet by providing essential nutrients like vitamins, minerals, carbohydrates, proteins (Ajit et al., 2018), among others. Hence, unravelling the potential nutritional benefits associated with the components of various fruits and fruit products (e.g. fruit wine) will enhance the intake of these food materials, thereby complementing legume and cereal grains in alleviating malnutrition.

Pineapple (Ananas comosus), the third most important fruit crop in the tropical and subtropical regions of the world is a tropical and economically significant plant from the family Bromeliaceae (D'Eeckenbrugge and Leal, 2003). Pineapple juice is rich in carbohydrates, proteins, energy, vitamins (vitamins A, $\mathrm{C}$, K, B6, $\beta$-carotene etc.), minerals (calcium, iron, magnesium, zinc, phosphorous etc.) and phenolic compounds such as gallic acid, chlorogenic acid, and ferulic acid, which have been shown to have anti-oxidative, anti-mutagenic, and anti-carcinogenic effects and have protective roles against cardiovascular diseases and cataracts (Tanriöven and Eksi, 2005). Besides, pawpaw (Carica papaya) belongs to the family Caricaceae, a native of tropical America, but now spread all over the tropical regions of the world (Morton, 2006). According to Augustine et al. (2013), pawpaw juice is rich in carbohydrates, proteins, crude fibre, lipid, energy, minerals (calcium, magnesium, copper etc.) and vitamins (vitamin C, A etc.).

The world cultivation of pawpaw and pineapple has improved with the increase in the world population in the past 40 years (Al-Shahib and Marshall, 2013), which shows that there is potential for more use of the fruits as food. Although the fruits are highly economical and rich in a galaxy of nutrients, they are still rarely consumed as part of our diet due to consumers largely being unaware of the potential benefits of their components (Al-Shahib and Marshall, 2013). The high perishability of ripe pawpaw and pineapple fruits encourages the disposal of large quantities of these fruits yearly due to lack of or poor storage facilities, resulting in loss of the vital nutrients contained in the fruit (Awe, 2011). A wide array of microorganisms, including Staphylococcus aureus, Candida spp., Aspergillus spp., Penicillium spp., Bacillus spp., Rhizopus spp., Lactobacillus spp., Fusarium spp. among others have been implicated in the spoilage of pineapple and pawpaw fruits (Chukwuka et al., 2010). The high level of wastage of these fruits coupled with their low level of industrial utilization in developing countries such as Nigeria therefore calls for great concern. Hence, fermenting the juices of these fruits into wine would contribute immensely to the fast-growing food need in the world, forestall wastage and also enhance the nutrient intake of the consumers.

Fermentation of foods has been recognized as an important tool for enhancing food security through food preservation, improving livelihoods, nutrition and social well-being of millions of people around the world, particularly the marginalised and vulnerable (Holzapfel, 2002). According to Etsuyankpa $\boldsymbol{e t}$ al. (2015), anti-nutrients are natural or synthetic compounds that interfere with the absorption of nutrients by reducing the body's ability to absorb or use essential nutrients like vitamins and minerals, and are found in all plant foods, although the types and amounts vary tremendously from food to food. However, the traditional method of food preservation such as fermentation has been observed to enhance the nutritive quality, digestibility and safety of plant foods by reducing certain anti-nutrients such as phytic acid, polyphenols and oxalic acid (Hotz and Gibson, 2007).

Wine is an alcoholic beverage produced from the fermentation of fruit juice. Grapes are more suitable for wine production, owing to the fact that the juices have natural chemical balance that allow them to ferment without addition of sugar, acids, enzymes or other nutrients (Reddy and Reddy, 2005). 
Nevertheless, success stories have been documented on the utilization of fruits other than grape (Awe, 2011) to produce wine; however; there is limited information on the combination of these fruits in wine production. Considering the important properties of these fruits, it is of more advantage to have blends of the fruits for wine production as it will enhance and improve the properties of the wine (Ajit et al., 2018). Apart from the limited information on pawpawpineapple wine, ascertaining the concentrations of the nutrients and anti-nutrient in the wine is considered vital as it will help to justify the potential ability of the wine in mitigating food insecurity and malnutrition in both the developed and developing world. Hence, this study was conducted to determine the role of fermentation on the nutritional and anti-nutritional compositions of pawpawpineapple juice blends using single and mixed starter cultures.

\section{MATERIALS AND METHODS}

\section{Collection of Fruits}

Apparently healthy fruits with intact protective skin of pawpaw and pineapple were purchased from Oye-Ekiti main market and transported to the Food Science and Technology Laboratory, Federal University Oye-Ekiti, Ekiti State for authentication before further investigation at Microbiology Laboratory of the same University.

\section{Isolation of Starter Cultures}

Pawpaw and pineapple juices were subjected to natural fermentation for 5 days a $30{ }^{\circ} \mathrm{C}$ and $37^{\circ} \mathrm{C}$. At every 24 hours of the processes, samples were taken for microbial isolation. Dilution factor 3 and 5 were cultured on Nutrient and Potato Dextrose agar respectively. The dominant microorganisms were subsequently identified using standard biochemical methods (Fawole and Oso, 2001). The pure cultures of these organisms were stored on agar slant and thereafter used as starter cultures.

\section{Preparation of Microorganisms}

Each of the test organisms from the slant was inoculated in nutrient broth and incubated for 18 hours at $37^{\circ} \mathrm{C}$. The 18 hours old broth culture was centrifuged to pellet cells and the supernatant was discarded. Pellet cells were washed with phosphate buffer saline 3 times to remove debris. The washed cells were resuspended in buffered saline and diluted to specific cell density using 0.5 Mcfarland for the fermentation processes. The yeast was prepared by culturing on potato dextrose agar slant for 10 days for sporulation to occur. The spores were collected after shaking the slant with sterile peptone water $(0.2 \%, \mathrm{w} / \mathrm{v})$ and then filtered through Whatman No. 2 to remove hyphal fragment (Magnusson and Schnurer, 2001). The yeast concentrations were then determined using a Buckner haemocytometer and thereafter diluted to specific cell density for the fermentation processes.

\section{Preparation of Samples}

The fruits were sorted out to remove any unhealthy ones among them. The fruits were washed thoroughly in the laboratory before their usage to remove dirts and other contaminants attached to the surface of the fruits. The fruits were peeled and the flesh was sliced into a dry cleaned jar. Different samples were prepared. The first category (Sample A) contains blended mixture of fruit samples in the same proportion (100 g each). The second category contains $50 \mathrm{~g}$ of pawpaw and $150 \mathrm{~g}$ of pineapple (Sample B), while the third category contains $150 \mathrm{~g}$ of pawpaw and $50 \mathrm{~g}$ of pineapple (Sample C) (Table 1). After blending, the juice was thereafter extracted by juice extractor for further processes.

Table 1 Formulation of pawpaw-pineapple juice blends

Sample Pawpaw (g)

The wine was produced using the method of Ogunbanwo and Ogunsanya (2012).

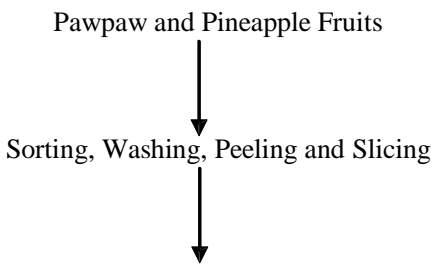

Preparation of samples in varying proportions $(1: 1,1: 3$ and $3: 1)$

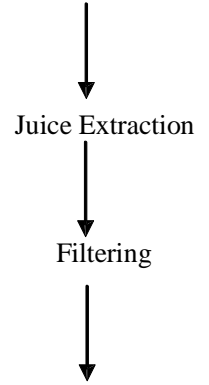

Addition of each Proportion into $500 \mathrm{ml}$ of sterile distilled water in a bioreactor<smiles>CO</smiles>

Treatment of sample with campden tablet of Sulphur dioxide $\left(\mathrm{SO}_{2}\right)$

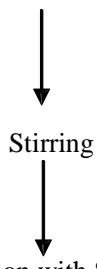

Aseptic Inoculation of each proportion with Starter Cultures at initial cell density of $2 \mathrm{OD}_{600}$

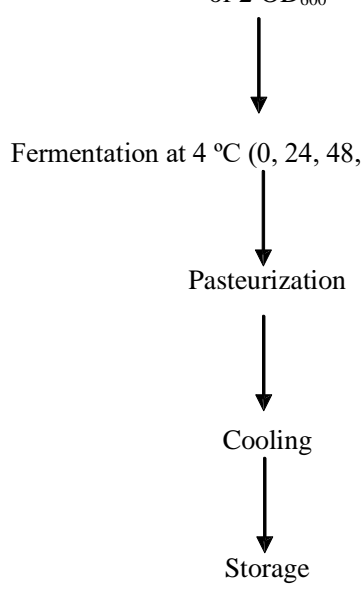

Figure 1 Production flow chart of Pawpaw-Pineapple wine Pineapple (g)

\section{Determination of Anti-Nutritional Content}

\begin{tabular}{lc}
$\mathrm{A}(1: 1)$ & 100 \\
$\mathrm{~B}(1: 3)$ & 50 \\
$\mathrm{C}(3: 1)$ & 150 \\
\hline
\end{tabular}

\section{Fermentation of Fruit Juice Blends Using Starter Cultures}

Each sample was added into $500 \mathrm{ml}$ of sterile distilled water in a bioreactor and treated with $44 \mathrm{mg}$ campden tablet of Sulphur dioxide $\left(\mathrm{SO}_{2}\right)$ and stirred. The samples were then heated for 3 minutes at $60{ }^{\circ} \mathrm{C}$. Each sample was aseptically inoculated with single or mixed starter cultures at an initial cell density of 2 $\mathrm{OD}_{600}$. The samples were made to undergo controlled-liquid state fermentation for 5 days under sterile conditions at $4{ }^{\circ} \mathrm{C}$ (Fig. 1). Un-inoculated treated samples were used as control. Samples were collected from each bioreactor and the proximate, mineral, and anti-nutrient compositions of the wine were determined.

\section{Qิ⿴囗十⺝nin}

15be tannin content was determined by measuring 20 milliliters each of the juice and indigo solution into1 L conical flask. Distilled deionized water $\left(\mathrm{ddH}_{2} \mathrm{O}\right)$ was 5 thereafter added into the flask to make the volume 800 milliliters. $0.1 \mathrm{~N} \mathrm{KMnO}_{4}$ for the carefully added until solution turns golden yellow. Standard solution of indigo was prepared by dissolving $6 \mathrm{~g}$ of indigo carmine in 500 milliliters of $\mathrm{ddH}_{2} \mathrm{O}$ by heating, after cooling 50 milliliters of $95 \% \mathrm{H}_{2} \mathrm{SO}_{4}$ was added, the solution was thereafter diluted to $1 \mathrm{~L}$ and filtered. For blanks, 20 milliliters of indigo and 760 milliliters of $\mathrm{ddH}_{2} \mathrm{O}$ was titrated.

$$
\mathrm{T}=\frac{\left(\mathrm{V}-\mathrm{V}_{\mathrm{O}}\right) \times 0.004157 \times 250}{\mathrm{~g} \times 20}
$$


T: Tannin content; $\mathrm{V}$ : volume of $0.1 \mathrm{~N}$ aqueous solution of $\mathrm{KMnO}_{4}$ for sample titration; $\mathrm{V}_{\mathrm{O}}$ : volume of $0.1 \mathrm{~N}$ aqueous solution of $\mathrm{KMnO}_{4}$ for blank titration; 0.004157: Tannins equivalent in 1 milliliter $0.1 \mathrm{~N}$ aqueous solution of $\mathrm{KMnO}_{4}, \mathrm{~g}$ mass of the sample taken for the analysis; 250: volume of the volumetric flask (Antanassova, 2009)

\section{Oxalate}

Oxalate was determined by titration using the method of Association of Official Analytical Chemists (AOAC, 2000). Two milliliters of the sample was weighed into $100 \mathrm{ml}$ conical flask and $50 \mathrm{ml}$ of $1.5 \mathrm{~N} \mathrm{H}_{2} \mathrm{SO}_{4}$ was added and stirred intermittently with a magnetic stirrer (Heated gathering type, Model number DF $101 \mathrm{~S}$ ) for $1 \mathrm{hr}$, and then filtered (Whatman N01). The filtrate $(25 \mathrm{ml})$ was transferred into another conical flask and filtrated at high temperature $\left(80-90^{\circ} \mathrm{C}\right)$ against $0.1 \mathrm{~N} \mathrm{KMnO}_{4}$ solution until a faint colour appearance that persist for at least 30 seconds.

Oxalate $=($ Titer value $\times 0.9004) \mathrm{mg}$.

\section{Determination of Proximate and Mineral Composition}

The moisture, ash, crude fibre, fat, protein, and carbohydrate contents, and mineral composition of the samples were analyzed using the standard methods of AOAC (AOAC, 2000).

\section{Determination of Percentage Alcohol}

To a $150 \mathrm{ml}$ graduated cylinder, $150 \mathrm{ml}$ of the sample was added. The content was transferred to a $200 \mathrm{ml}$ boiling flask for distillation. A graduated cylinder $(250 \mathrm{ml})$ was placed under the output of the condensers to collect the distillate The contents were allowed to cool to room temperature. Distilled water was added to the distillate until the volume reached $150 \mathrm{ml}$ (the same volume as the original sample). A specific gravity hydrometer was used to measure the specific gravity of the distillate at room temperature. The following equation was then applied to convert specific gravity to percentage alcohol (Ferguson 2000).

Percentage of alcohol $=((1.05 \times(\mathrm{OG}-\mathrm{TG})) / \mathrm{TG}) / 0.79$

Where $\mathrm{OG}=$ Original gravity, $\mathrm{TG}=$ Terminal gravity

\section{Statistical Analysis}

This was carried out using Statistical Package for Social Sciences (SPSS) 15.0 for windows evaluation version by using Analysis of Variance (ANOVA) and Duncan's Multiple Range Test for the separation of means at 95\% Confidence Interval.

\section{RESULTS}

Effects of Single and Mixed Starter Cultures on the Proximate Composition of Sample A (1:1)

The findings revealed an increase in the level of all the proximate parameters as compared to the control except carbohydrate level that was observed to decrease with increased fermentation time. It was also observed that the maximum protein content value in sample A was produced by a single culture of $L$. mesenteroides $(10.33 \pm 0.58 \%)$, followed by $S$. cerevisiae $(9.33 \pm 0.58 \%)$. The fermentation of sample A, using a single starter culture of $L$. delbreukii and $S$. cerevisiae yielded the highest ash content value of $4.67 \pm 0.58 \%$. However, L. mesenteroides was observed to produce the highest fiber $(6.00 \pm 0.00 \%)$ and carbohydrate $(14.67 \pm 0.58 \%)$ values at the end of the fermentation process. In the same vein the proximate analysis of sample A depicted that the fermentation processes of the mixed culture of $L$. delbreukii and $L$. mesenteroides enhanced the concentration of all the proximate parameters except carbohydrate (Fig. 2a).

Effects of Single Starter Cultures on the Proximate Composition of Sample B (1:3)

All the fermenting organisms increased the level of all the proximate parameters, excluding carbohydrate. The fermentation process of a single culture of $S$. cerevisiae in sample B produced the maximum protein and ash content values $(8.00 \pm 0.00 \%$ and $4.00 \pm 0.00 \%)$ respectively. Moreover, the sample that was fermented with a single culture of $L$. delbreukii was found to yield the highest fiber $(2.67 \pm 0.58 \%)$ and fat $(8.00 \pm 0.00 \%)$ contents on the last day of the fermentation process. The exploitation of a single culture of $L$. mesenteroides in fermenting sample $B$ produced the maximum moisture content value $(76.33 \pm 0.58 \%)$. After the fifth day of fermentation, the highest carbohydrate content value was recorded in sample fermented with a single culture of $S$. cerevisiae (11.67 $\pm 0.58 \%$ ) (Fig. 2 b).

\section{Effects of Single Starter Cultures on the Proximate Composition of Sample C (3:1)}

At the end of the fermentation process, only carbohydrate level was observed to decrease as compared to the control. The maximum protein $(5.67 \pm 0.58 \%)$, ash $(3.00 \pm 0.00 \%)$, and fat $(7.33 \pm 0.58 \%)$ content values were observed in the sample fermented with a single culture of $S$. cerevisiae. Samples fermented with a single culture of $L$. mesenteroides and S. cerevisiae exhibited the maximum fiber content value of $3.67 \pm 0.58 \%$. Moreover, L. mesenteroides was observed to produce the highest carbohydrate value $(6.67 \pm 0.58 \%)$ at the end of the fermentation process (Fig. 2c).
A

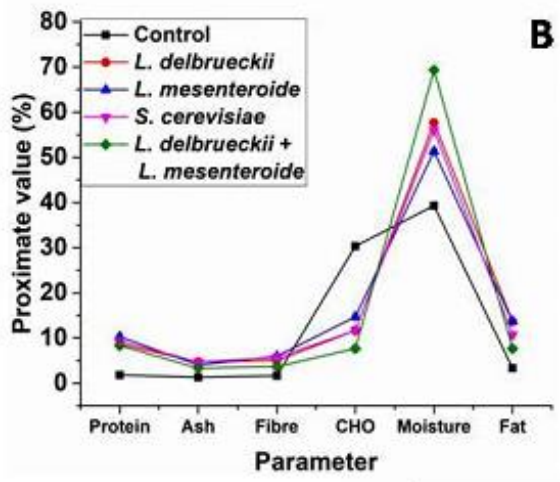

B

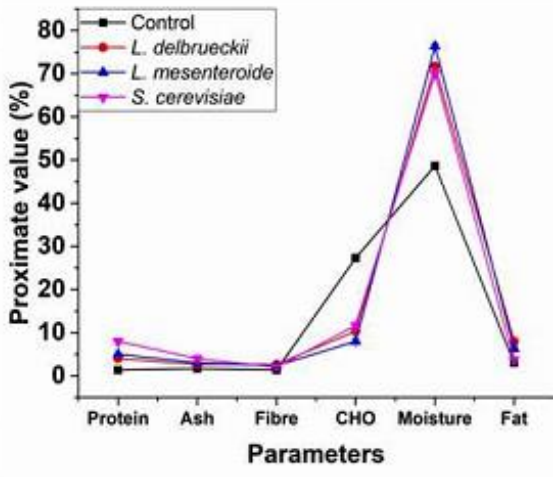

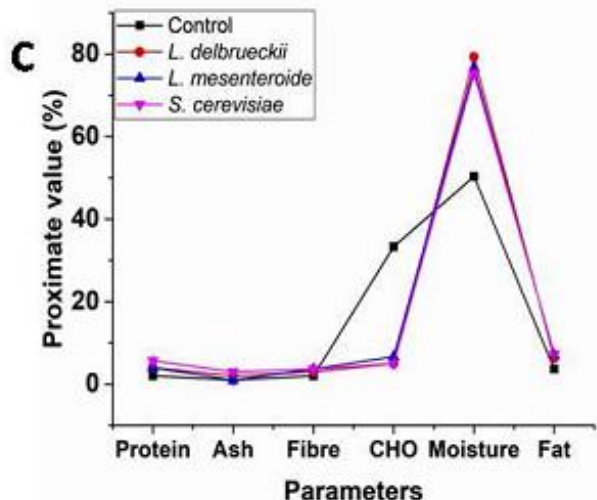

Figure 2 A Effects of single and mixed starter culture on the proximate composition of sample A (1:1), B. Effects of single starter culture on the proximate composition of sample B (1:3), C. Effects of single starter culture on the proximate composition of sample C (3:1), after the fifth day of fermentation. Three parallel flasks are tested for each organism. Error bars represent deviations $(\mathrm{n}=3)$. Statistically significant differences $(\mathrm{P}<0.05)$ were determined by student's $t$ test. $L$. delbreukii= Lactobacillus delbreukii, L. mesenteroide $=$ Leuconostoc mesenteroides, $\mathrm{CHO}=$ Carbohydrate 
Effects of Single and Mixed Starter Cultures on the Mineral Composition of all the Blended Ratios

The results revealed a high amount of sodium, potassium and calcium in all the blended ratios. However, sample A gave the highest mineral composition with respect to organism after the fermentation processes. There were variations in the mineral outputs of both single and mixed starter cultures. Overall, a single starter culture of $S$. cerevisiae produced the highest mineral output in all the blended ratios. For instance, mono-cultural fermentation of sample A by $S$. cerevisiae produced sodium, potassium and calcium output values of $800 \pm 0.00 \mathrm{mg} / \mathrm{ml}$ $2600 \pm 0.00 \mathrm{mg} / \mathrm{ml}$ and $650 \pm 0.00 \mathrm{mg} / \mathrm{ml}$ while mixed culture fermentation gave $750 \pm 0.00 \mathrm{mg} / \mathrm{ml}, 2000 \pm 0.00 \mathrm{mg} / \mathrm{ml}$ and $640 \pm 0.00 \mathrm{mg} / \mathrm{ml}$ respectively (Table 2 )

Table 2 Effects of single and mixed starter cultures on the mineral composition of pawpaw-pineapple juice blends in varying proportions after 5 days fermentation

\begin{tabular}{|c|c|c|c|c|c|c|}
\hline \multirow[b]{2}{*}{ Samples } & \multirow[b]{2}{*}{$\begin{array}{l}\text { Minerals } \\
(\mathrm{mg} / 100 \mathrm{ml})\end{array}$} & \multicolumn{5}{|c|}{ SINGLE AND MIXED STARTER CULTURES } \\
\hline & & Control & L. delbreukii & L. mesenteroides & S. cerevisiae & $\begin{array}{l}\text { L. delbreukii+ } \\
\text { L. mesenteroides }\end{array}$ \\
\hline \multirow[t]{3}{*}{$\mathrm{A}$} & $\mathrm{Na}$ & $600 \pm 0.00^{\mathrm{a}}$ & $700 \pm 0.00^{\mathrm{c}}$ & $600 \pm 0.00^{\mathrm{a}}$ & $800 \pm 0.00^{\mathrm{d}}$ & $750 \pm 0.00^{\mathrm{b}}$ \\
\hline & $\mathrm{K}$ & $1400 \pm 0.00^{\mathrm{a}}$ & $1800 \pm 0.00^{\mathrm{c}}$ & $1600 \pm 0.00^{\mathrm{b}}$ & $2600 \pm 0.00^{\mathrm{e}}$ & $2000 \pm 0.00^{\mathrm{d}}$ \\
\hline & $\mathrm{Ca}$ & $500 \pm 0.00^{\mathrm{a}}$ & $620 \pm 0.00^{\mathrm{b}}$ & $610 \pm 0.00^{\mathrm{b}}$ & $650 \pm 0.00^{\mathrm{c}}$ & $640 \pm 0.00^{\mathrm{c}}$ \\
\hline \multirow[t]{3}{*}{ B } & $\mathrm{Na}$ & $600 \pm 0.00^{\mathrm{c}}$ & $550 \pm 0.00^{\mathrm{a}}$ & $580 \pm 0.00^{\mathrm{b}}$ & $620 \pm 0.00^{\mathrm{d}}$ & $600 \pm 0.00^{\mathrm{c}}$ \\
\hline & $\mathrm{K}$ & $1400 \pm 0.00^{\mathrm{a}}$ & $1200 \pm 0.00^{\mathrm{a}}$ & $1300 \pm 0.00^{\mathrm{a}}$ & $1700 \pm 0.00^{\mathrm{b}}$ & $1500 \pm 0.00^{\mathrm{b}}$ \\
\hline & $\mathrm{Ca}$ & $500 \pm 0.00^{\mathrm{a}}$ & $510 \pm 0.00^{\mathrm{a}}$ & $550 \pm 0.00^{\mathrm{b}}$ & $550 \pm 0.00^{\mathrm{b}}$ & $590 \pm 0.00^{\mathrm{c}}$ \\
\hline \multirow[t]{3}{*}{$\mathrm{C}$} & $\mathrm{Na}$ & $600 \pm 0.00^{\mathrm{b}}$ & $600 \pm 0.00^{\mathrm{b}}$ & $550 \pm 0.00^{\mathrm{a}}$ & $600 \pm 0.00^{\mathrm{b}}$ & $620 \pm 0.00^{\mathrm{c}}$ \\
\hline & $\mathrm{K}$ & $1400 \pm 0.00^{\mathrm{a}}$ & $1600 \pm 0.00^{\mathrm{a}}$ & $1800 \pm 0.00^{\mathrm{b}}$ & $2200 \pm 0.00^{c}$ & $1800 \pm 0.00^{\mathrm{b}}$ \\
\hline & $\mathrm{Ca}$ & $500 \pm 0.00^{\mathrm{a}}$ & $500 \pm 0.00^{\mathrm{a}}$ & $500 \pm 0.00^{\mathrm{a}}$ & $630 \pm 0.00^{\mathrm{c}}$ & $540 \pm 0.00^{\mathrm{b}}$ \\
\hline
\end{tabular}

Keys: L. delbreukii= Lactobacillus delbreukii, L. mesenteroides = Leuconostoc mesenteroides, S. cerevisiae $=$ Saccharomyces cerevisiae, $\mathrm{Na}=$ Sodium, $\mathrm{K}=$ Potassium, $\mathrm{Ca}=$ Calcium

Effects of Single and Mixed Starter Cultures on the Anti-Nutritional Composition of all the Blended Ratios

In all the blended ratios, both the single and mixed starter cultures considerably reduced the levels of the examined anti-nutritional factors. However, there was variation in the extent to which the organisms exhibited effect on the anti-nutrient compounds present in the sample. The reduction of the anti-nutritional factors in all the blended ratios was observed to be more pronounced on a single starter culture of $S$. cerevisiae than mixed and single culture of $L$. delbreukii and $L$. mesenteroides. For example, the $33.00 \pm 0.00 \mathrm{mg} / 100 \mathrm{ml}$ tannin compound found in sample A was reduced to $24.50 \pm 0.00 \mathrm{mg} / 100 \mathrm{ml}, 26.00 \pm 0.00 \mathrm{mg} / \mathrm{ml}$ $29.10 \pm 1.73 \mathrm{mg} / 100 \mathrm{ml}$ and $30.00 \pm 0.00 \mathrm{mg} / \mathrm{ml}$ by single culture of $S$. cerevisiae mixed and single culture of $L$. delbreukii and $L$. mesenteroides respectively (Table 3).

Table 3 Effects of single and mixed starter cultures on the anti-nutritional components of pawpaw-pineapple juice blends in varying proportions after 5 days of fermentation

SINGLE AND MIXED STARTER CULTURES

\begin{tabular}{|c|c|c|c|c|c|c|}
\hline Samples & $\begin{array}{l}\text { Anti-nutrients } \\
(\mathrm{mg} / 100 \mathrm{ml})\end{array}$ & Control & L. delbreukii & L. mesenteroides & S. cerevisiae & $\begin{array}{l}\text { L. delbreukiit } \\
\text { L. mesenteroides }\end{array}$ \\
\hline A & Tannin & $33.00 \pm 0.00^{\mathrm{e}}$ & $29.10 \pm 1.73^{c}$ & $30.00 \pm 0.00^{\mathrm{d}}$ & $24.50 \pm 0.00^{\mathrm{a}}$ & $26.00 \pm 0.00^{\mathrm{b}}$ \\
\hline B & Tannin & $33.10 \pm 1.73^{\mathrm{c}}$ & $33.10 \pm 1.15^{\mathrm{c}}$ & $33.00 \pm 0.00^{\mathrm{c}}$ & $30.00 \pm 0.00^{\mathrm{a}}$ & $31.00 \pm 0.00^{\mathrm{b}}$ \\
\hline \multirow[t]{2}{*}{$\mathrm{C}$} & Tannin & $32.40 \pm 0.00^{\mathrm{d}}$ & $32.00 \pm 0.00^{\mathrm{d}}$ & $30.60 \pm 0.58^{\mathrm{a}}$ & $29.40 \pm 1.15^{\mathrm{a}}$ & $30.00 \pm 0.00^{\mathrm{c}}$ \\
\hline & Oxalate & $11.00 \pm 0.00^{\mathrm{c}}$ & $10.00 \pm 0.00^{\mathrm{b}}$ & $10.10 \pm 1.00^{\mathrm{b}}$ & $9.40 \pm 0.00^{\mathrm{a}}$ & $9.60 \pm 2.65^{\mathrm{a}}$ \\
\hline
\end{tabular}

Keys: L. delbreukii= Lactobacillus delbreukii, L. mesenteroides= Leuconostoc mesenteroides, S. cerevisiae = Saccharomyces cerevisia

Effects of Single and Mixed Starter Cultures on the Alcoholic Content of Pawpaw-Pineapple Juice Blends

The findings revealed that both single and mixed culture fermentation processes resulted in the production of a considerable amount of alcohol in all the blended

Table 4 Effects of both single and mixed starter cultures on the alcoholic content of blended fruits mixed in different proportion after 5 days of fermentation.

\begin{tabular}{|c|c|c|c|c|}
\hline \multirow[b]{2}{*}{ Samples } & \multicolumn{4}{|c|}{ SINGLE AND MIXED STARTER CULTURES } \\
\hline & $\begin{array}{l}\text { L. } \\
\text { delbreukii }\end{array}$ & $\begin{array}{l}L . \\
\text { mesenteroides }\end{array}$ & $\begin{array}{l}S . \\
\text { cerevisiae }\end{array}$ & $\begin{array}{l}\text { L. delbreukii+ } \\
\text { L. mesenteroides }\end{array}$ \\
\hline $\mathrm{A}(\%)$ & $1.57 \pm 0.06^{\mathrm{a}}$ & $1.73 \pm 0.06^{\mathrm{b}}$ & $3.00 \pm 0.00^{\mathrm{d}}$ & $2.33 \pm 0.12^{\mathrm{c}}$ \\
\hline $\mathrm{B}(\%)$ & $1.20 \pm 0.00^{\mathrm{b}}$ & $1.00 \pm 0.00^{\mathrm{a}}$ & $2.47 \pm 0.06^{\mathrm{d}}$ & $1.77 \pm 0.06^{\mathrm{c}}$ \\
\hline $\mathrm{C}(\%)$ & $1.30 \pm 0.06^{\mathrm{a}}$ & $1.50 \pm 0.00^{\mathrm{b}}$ & $2.60 \pm 0.00^{\mathrm{d}}$ & $1.93 \pm 0.06^{\mathrm{c}}$ \\
\hline
\end{tabular}

Keys: L. delbreukii= Lactobacillus delbreukii, L. mesenteroides= Leuconostoc mesenteroides, S. cerevisiae= Saccharomyces cerevisiae

\section{DISCUSSION}

The use of starter culture in wine production has been found to be more productive than natural fermentation, owing to its advantages such as reduction in fermentation time and enhancement of nutritive quality in wine (Omafuvbe $\boldsymbol{e}$ al., 2002). Moreover, wines from the combination of two or more local fruits have been observed to have a positive cumulative health benefits than single fruit wines (Asuk $\boldsymbol{e t}$ al., 2011). In view of this, efforts had been made towards the production of varieties of wine from the combination of different local fruits: however, the benefits associated with pawpaw-pineapple wine with respect to alleviation of malnutrition and food insecurity are yet to be unravelled.

The combination of local fruits for wine production could probably result in an additional increase in anti-nutritional factors, whose excess consumption has been linked with health disorders such as infertility problems, kidney irritation, 
liver damage (Lilian, 2003) etc. Consequently, Ifemeje $\boldsymbol{e t}$ al. (2014) advocated moderate consumption of these phytochemicals to forestall them from serving as anti-nutrients to our bodies. On this note, we envisaged based on the reported abilities of some microbes to use anti-nutrients for metabolic activity (Etsuyankpa et al., 2015), that the fermenting organisms utilized in the present study will reduce the levels of the anti-nutrients, leading to the liberation of nutrients that form complexes with them and hence, achieving wine with little or no anti-nutritional factors and improved nutritive quality.

In agreement with our expectation, the fermenting organisms significantly reduced the concentrations of the examined anti-nutrients. However, the antinutrients were better reduced by a single culture of $S$. cerevisiae. This finding contradicts that of Sindhu and Khetarpaul (2014), where mixed culture fermentation was observed to be more effective in reducing anti-nutritional factors than a mono-cultural fermentation, although this mixed culture fermentation involved lactobacilli and yeast. An Exploration into the proximate and mineral compositions of the wines produced from all the blended ratios revealed that samples mixed in ratio 1:1 (sample A) gave the highest nutritional value, most especially the sample that was fermented with a single starter culture of $S$. cerevisiae. This suggests that nutrients and anti-nutrients in sample A were probably more readily available for the metabolic activity of the culture than samples mixed in ratio 1:3 and 3:1 (sample B and C respectively). Moreover, the use of a mono-cultural fermentation on sample $\mathrm{A}$ was found to be more productive with respect to enhancing the proximate composition of wine than mixed culture fermentation. The observed less productivity of the mixed culture fermentation may be due to the synergistic effect of these organisms in respect to acid production, which might further enhance their sensitivity to the antimicrobial effect of $\mathrm{SO}_{2}$ that was added to the juice (Quirós et al., 2012); however, further work is needed to ascertain this phenomenon.

The observed increase in protein in the present study could be linked to the increased activity of the microbial proteolytic enzymes that released more free amino acids into the fermenting medium (Chikwendu et al., 2014). Furthermore, the augmentation of the crude fat by the fermenting organisms could be as a result of extensive break-down of large molecules of fat into simple fatty acids (Jokotagba et al., 2015). The increased levels of dietary fibre in the fermented pawpaw-pineapple wine indicates that the wine would offer protection against cardiovascular disease, obesity and colon cancer and promote the effective functioning of the human digestive tract as reported by Ubom (2007). The observed increase in moisture content of all the blended ratios may be attributed to the availability of free bond water in the fermentation medium, the autolysis action of the microorganisms and presence of large volume of water in the medium (Adeleke, et al., 2017). The increase in ash content may be due to contribution by fermentation microorganisms in the breakdown of the organic components of the fruit samples during the period of fermentation (Oladele and Oshodi, 2008) while the ability of microbes to metabolize carbohydrate as carbon source to synthesize cell biomass could be attributed to the observed decrease in carbohydrate content of all the blended ratios (Ojokoh et al., 2013).

The use of anti-nutrients by microorganisms for metabolic activity usually results in the release of nutrients, including minerals that form complexes with them, although this ability varies from organism to organism, and so do amount of nutrients released differs. This may therefore be attributed to the variations in the mineral outputs of the fermenting organisms observed in the present study. Investigation into the alcoholic content of the wines produced from all the blended ratios revealed highest percentage of alcohol in the sample that was fermented with a single starter culture of $S$. cerevisiae. This finding complies with that of Okunowo et al. (2005), who stated that fruit wines with alcoholic content above $2 \%$ are comparable with moderate grape wines.

The current data in the present study strongly imply that the mono-cultura fermentation of pawpaw-pineapple juice in ratio $1: 1$ by $S$. cerevisiae will not only greatly improve the safety of the wine by reducing anti-nutritional factors, but it will also contribute immensely to mitigating food insecurity and malnutrition in both developed and developing world.

\section{CONCLUSIONS}

The results indicated that the concentrations of the proximate parameters, including the protein, ash, fibre, moisture and fat contents were enhanced by the fermentation process with a reduction in carbohydrate content. The wine produced from sample A using a single starter culture of $S$. cerevisiae was observed to be more nutritious than those produced from sample B and C using a single culture of $S$. cerevisiae, mixed and single culture of $L$. delbreukii and $L$ mesenteroides. It can therefore be concluded that the mono-cultural fermentation of pawpaw-pineapple juice in ratio $1: 1$ by $S$. cerevisiae is most efficient in obtaining the highest nutritional value and alcoholic content in pawpawpineapple wine. Hence, it is recommended that the industrial utilization of pineapple and pawpaw fruits in wine production should involve the combination of pawpaw-pineapple juice blends in the same ratio and fermenting with a single starter culture of S. cerevisiae.

Conflicts of interest: The authors declare that there are no conflicts of interest regarding the publication of this paper.
Acknowledgements: The authors acknowledge the support of the Department of Food Science and Technology and the Department of Microbiology, Federal University Oye-Ekiti, Ekiti State, Nigeria.

\section{REFERENCES}

Adeleke, B. S., Akinyele, B. J., Olaniyi, O. O. \& Jeff-Agboola, Y. A. (2017) Effect of Fermentation on Chemical Composition of Cassava Peels. Asian Journal of Plant Science and Research, 7(1), 31-38.

Ajit, E. J., Dominic, D., Farook, F., Promod, A., Bhagya, M. S., Kumar, B. V. J. \& Pratap, C. R. (2018) Preparation of wine from fruits of Musa accuminata and Ananas comosus; its physico-chemical analyses and sensory evaluation Integrative Food, Nutrition and Metabolism, 5(6), 1-5. http://dx.doi.org/10.15761/IFNM.1000232

Al-Shahib, W. \& Marshall, R. J. (2013) "The fruit of the date palm: Its possible use as the best food for the future? International Journal of Food Sciences and Nutrition, 54(4), 247-259. http://dx.doi.org/10.1080/09637480120091982

AOAC (2000). Official Methods of Analysis. Association of Official Analytical Chemists. $17^{\text {th }}$ ed. AOAC International, Washington D.C.

Asuk, A. A., Umoh, I. B., Eteng, M. U., Jayeola, C. O. \& Akpanyung, E. O. (2011) Production, characterization and safety of wine obtained from a blend of tomato, almond, orange, lemon and African star apple extract. Annals of

http://scholarsresearchlibrary.com/archive.htm

Atanassova, M. \& Christova-Bagdassarian, V. (2009) Determination of Tannins Content by Titrimetric Method for comparison of different plant species. Journal of the University of Chemical Technology and Metallurgy, 44(4) 413-415. https://www.researchgate.net/publication/257076247

Augustine, C. O., Christian, I. A. \& Glory, E. E. (2013) A Comparative Study of the Nutritive Factors and sensory acceptance of Juices from Selected Nigerian Fruits. Croatian Journal of Food Technology, Biotechnology and Nutrition, 8(12), 47-51. https://www.researchgate.net/publication/313861193

Awe, S. (2011) Production and microbiology of pawpaw (Carica papaya L) wine. Current Research Journal in Biological Science, 3(5), 443-447.

Chikwendu, J. N., Obiakor-Okeke, P. N. \& Maduforo, A. N. (2014) Effect of Fermentation on the Nutrient and Antinutrient Composition of African Yam Bean (Sphenostylisstenocarpa) Seeds and Pearl Millet (Pennisetum glaucum) Grains. The International Journal of Science and Technoledge, 2(12), 169-173. https://www.researchgate.net/publication/288831956

Chukwuka, K. S., Okonko, I. O. \& Adekunle, A. A. (2010) Microbial ecology of organisms causing pawpaw (Carica papaya L.) Fruit decay in Oyo State, Nigeria. American-eurasian Journal of Toxicological Sciences, 2(1), 43-50.

D'Eeckenbrugge, C. G. \& Leal, F. (2003) Morphology, Anatomy, and Taxonomy. In: Bartholomew DP, Paull RE \& Rohrbach KG (eds). The Pineapple: Botany, Production, and Uses. Wallingford: CABI Publishing, 21. Etsuyankpa, M. B., Gimba, C. E., Agbaji, E. B., Omoniyi, K. I., Ndamitso, M. M. \& Mathew, J. T. (2015) Assessment of the Effects of Microbial Fermentation on Selected Anti-Nutrients in the Products of Four Local Cassava Varieties from Niger State, Nigeria. American Journal of Food Science and Technology, 3(3), 89-96. http://dx.doi.org/10.12691/ajfst-3-3-6

Fawole, M. O. \& Oso, B. A. (2001) Laboratory Manual of Microbiology. Spectrum Books Limited. Ibadan, Nigeria, 127.

Ferguson, J. (2000) Determination of Alcohol content of wine by distillation followed by density determination by hygrometer. Sirromet nWines Pty Ltd. Downloaded from seniorchem.com/eei.html.

Holzapfel, W. H. (2002) Appropriate starter culture technologies for small-scale fermentation indeveloping countries. International Journal of Food Microbiology, 75, 197-212. http://dx.doi.org/10.1016/S0168-1605(01)00707-3

Hotz, C. \& Gibson, R. S. (2007) Traditional food-processing and preparation practices to enhance the bioavailability of micronutrients in plant-based diets Journal of Nutrition, 137(4), 1097-1100. http://dx.doi.org/10.1093/jn/137.4.1097 Ifemeje, J. C., Egbuna, C., Eziokwudiaso, J. O. \& Ezebuo, F. C. (2014) Determination of the Anti-nutrient Composition of Ocimum gratissimum Corchorus olitorius, Murraya koenigii Spreng and Cucurbita maxima. International Journal of Innovation and Scientific Research, 3(2), 127-133.

Jokotagba, O. A., Onasanya, S. S. \& Akinbile, A. A. (2015) The Impact of Fermentation on the Proximate and Mineral Composition of Phoenix dactylifera $L$ Flour. Covenant Journal of Physical and Life Sciences, 3(1).

Latham, M. C. (1997) Human Nutrition in the Developing World FAO, Rome, Italy.

Lilian, U. T. (2003) Potential health benefits and problems associated with antinutrients in foods. Food Research International, 26(2), 131-149. https://doi.org/10.1016/0963-9969(93)90069-U

Magnusson, J. \& Schnurer, J. (2001) Lactobacillus coryniformis Subsp. Coryniformis Strain Si3 Produces a Broad-Spectrum Proteinaceous Antifungal Compound. Applied and Environmental Microbiology, 67, 1-5. http://dx.doi.org/10.1128/AEM.67.1.1-5.2001

Morton, J. (2006) Papaya: Carica papaya L. Retrieved from http://www.hotrpuredue.edu/newcrop/morton/papayaars.html 
Ogunbanwo, S. T. \& Ogunsanya, B. T. (2012) Quality assessment of 'oti-oka' like beverage produced from pearl millet. Journal of Applied Biosciences, 51:3608-3617.

Ojokoh, A. O., Daramola, M. K. \& Oluoti, O. J. (2013) Effect of fermentation on nutrient and anti-nutrient composition of breadfruit (Treculia africana) and cowpea (Vigna unguiculata) blend flours. African Journal of Agricultural Research, 8(27), 3566-3570. http://dx.doi.org/10.5897/AJAR12.1944

Okunowo, W. O., Okotore, R. O. \& Osuntoki, A. A. (2005) The alcoholic fermentative efficiency of indigenous yeast strains of different origin on orange juice. African Journal of Biotechnology, 4:1290-1296.

Oladele, E. P. \& Oshodi, A. A. (2008) Effect of fermentation on some chemical and Nutritiveproperties of Berlandier nettle spurge (Jatropha cathartica) and physic Nut (Jatrophacurcas) seeds. Pakistan Journal of Nutrition, 7, 292-296. http://dx.doi.org/10.3923/pjn.2008.292.296

Omafuvbe, B. O., Abiose, S. H. \& Shonukan, O. O. (2002) Fermentation of soybean (Glycine max) for soy-daddawa production by starter cultures of Bacillus. Food Microbiolology, $\quad 19, \quad 561-566$ http://dx.doi.org/10.1006/fmic.2002.0513

Quirós, C., Herrero, M., García, L. A. \& Díaz, M. (2012) Effects of $\mathrm{SO}_{2}$ on lactic acid bacteria physiology when used as a preservative compound in malolactic fermentation. Journal of the Institute of Brewing, 118, 89-96. http://dx.doi.org/10.1002/jib.9

Reddy, L. V. \& Reddy, O. V. S. (2005) Production and characterization of wine from mango fruit (Mangifera indica). World Journal of Microbioliology and Biotechnology, 21, 1345-1350.

Sindhu, C. S. \& Khetarpaul, N. (2014) Probiotic Fermentation of Indigenous Food Mixture: Effect of Anti-nutrients and Digestibility of Starch and Protein. Journal of Food Composition and Analysis, 14, 601-609. http://dx.doi.org/10.1006/jfca.2001.1022

Tanriöven, D. \& Eksi, A. (2005) Phenolic compounds in pear juice from different $\begin{array}{llll}\text { cultivars. } & \text { Food Chemistry, } & \text { 89-93. }\end{array}$ http://dx.doi.org/10.1016/j.foodchem.2004.09.009

Ubom, D. E. (2007) Nutrition, health and our environment. Sendina Ltd, Nigeria, 140 . 